\title{
Environmental Policy-Making in New Zealand, 1978-2013
}

This article examines the ways in which key environmental policies have been made in the past, and reflects on the present state of play with respect to these policies. The article draws on my experience with the Environmental Defence Society (EDS) since 1978 and the reflections are personal ones. The issues covered are: government agencies; climate change; oceans; freshwater; and resource management law. The objective of this discussion is to see if the past illuminates the present in any useful way.

\section{Government agencies: then}

In 1984 a Labour government was elected with a policy of restructuring the public service to create a Ministry for the Environment. The spokesperson on the environment for Labour, Michael Cullen, said in June 1983:

The time has arrived for the creation of a Ministry for the Environment, a full-fledged Department of State. Such a Ministry would be responsible for advice and the co-ordination and implementation of environmental policy. It would incorporate within it a number of existing divisions of other departments most notably those relating to wildlife, water and soil conservation, native forests, national parks and reserves, other

Gary Taylor is the chairman of the Environmental Defence Society, with which he has been involved since the late 1970s. He is an environmental policy analyst and has had extensive governance experience as a director of public sector entities in Auckland.

forms of reserves and environmental health. (Cullen, 1983)

The environmental movement had joined together - not for the last time - and contended that we needed a focused ministry as an alternative to the 'scattered green blobs' approach whereby each government agency had its own environmental capacity. In Environmental Administration in New Zealand: an alternative discussion paper, released by six environmental groups in January 1985, it was noted that an era of 'confrontation politics ... in which the formidable machinery of the State was used for single-minded promotion of natural resource exploitation' had come to an end (Royal Forest and Bird Protection Society et al., 1985). The expectation was that a reorganised public service would promote the concept of sustainability as an alternative to the then discredited 'Think Big' era of the earlier 1980s.

What eventuated was that instead of a single large entity which had both policy and operational functions, the Labour government created a more tightly focused Ministry for the Environment, with operational functions largely delegated to territorial councils. At the time it was 
described as being to the environment what Treasury is to the economy: a socalled control agency.

Labour also created a separate Department of Conservation to run the new protected lands, responsibility for which had been assimilated from the old Forest Service and Lands and Survey Department. The Wildlife Service was also folded into the department. The enabling act gave it special functions for the management of public resources: freshwater and the coastal environment. It was also given the role of being an advocate for nature on private land.

The department had a troubled start. During its first three years of life it had three different ministers and three directors-general. It went through a major restructuring in 1989, only two years after its establishment, as a result of which 188 staff were made redundant, a management tier was removed, and regional conservators now reported directly to the director-general. A minor review during 1993 and 1994 led to a further 38 staff being made redundant to save costs. Funding was so tight that by 1995 'vehicles were put up on blocks owing to lack of funds for running them' (Eriksen et al., 2004).

A defining point in the department's history was the Cave Creek disaster in April 1995, when a viewing platform in the Paparoa National Park collapsed, killing 14 people. The political fallout was significant, absorbing much management and staff attention, and the department went through another restructuring a year later. This reduced the number of conservancies from 14 to 13 and established three regional offices. Restructuring has been a regular feature of the department's life since.

The administrative reforms that created the Ministry for the Environment and the Department of Conservation in the late 1980 s were the result of some effective lobbying by civil society. There were town hall meetings, the presence of environmental lobbyists in the corridors of Parliament, the production of discussion papers and pamphlets and the expending of a lot of energy. A groundswell of public support in the early 1980 os led to Labour making reform commitments

prior to its election; though it was very much a reforming government. It is fair to say that, although it has been tinkered with over the years, the environmental framework that was created has remained intact: it has stood the test of time. To the best of my knowledge no credible political party is advocating fundamental structural change to either the Ministry for the Environment or the Department of Conservation.

\section{A defining point in the [Department of Converstion's] history was the Cave Creek disaster in April 1995, when a viewing platform in the Paparoa National Park collapsed, killing 14 people.}

\section{Government agencies: now}

Recently, however, further restructuring of the Department of Conservation has created two new divisions, an operating division (Conservation Services) and a partnerships division (Conservation Partnerships) (Department of Conservation, 2013). The partnerships division seems based on the assumption that there is a lot of voluntary and sponsorship support for the department in the corporate and non-government sectors, and that the department needs to be divided to best appropriate that support.

This has been a very difficult reform to understand. One can imagine that the department might have piloted such a scheme on a smaller scale; to embark on such an experiment seems risky when there are no guarantees that the expected level of sponsor and volunteer interest will manifest itself. It is also hard to say how the collapse of many conservancies into a less-devolved structure will work.

It means, too, that the department is now competing for sponsorship funding, as a government entity funded by tax revenues, with the third sector: groups such as EDS, WWF-New Zealand and Forest and Bird. Funding for the third sector is very limited too, and it seems unfair to have this hugely-resourced government entity in direct competition with not-for-profit environmental NGOs. At the same time, the department has been progressively reducing its statutory advocacy role with respect to nature on private land. This also puts more pressure on the thin green line of environmental NGOs, and Fish and Game, to take up the slack, while also being asked to continue and even extend voluntary effort. So it is a double strike more competition for scarce sponsorship dollars while at the same time more work is being pushed our way.

In contrast to the process that created the Department of Conservation, there was no external consultation about these changes. It was an initiative led by the director-general and conducted entirely in-house. Restructuring is, of course, a chief executive's prerogative. However, in this case it has serious implications for other parties, is a major restructuring which could have benefited from some external input, and relates to the conservation estate which the department manages with assistance from many NGOs. The department is now a different creature; and the new directorgeneral may have his own views on further change. While change has been a part of the department since its creation, and refreshing the way things are done is valid, too much change is debilitating and inevitably sees a loss of knowledge and experience. The department needs a period of stability, but I question whether it has the right platform in place.

\section{Climate change: then}

Here I want to traverse the creation of New Zealand's policy responses to climate change, clearly the biggest environmental issue facing the planet today. 
The Kyoto Protocol was negotiated in 1997, and the minister for the environment, Simon Upton, signed New Zealand up to it in 1998. It was ratified by the Helen Clark-led Labour government in December 2002. Ratification brought with it legally-binding obligations to reduce greenhouse gas emissions. During the first commitment period, 2008-12, New Zealand was required to reduce emissions to 1990 levels, or to top up any shortfall by way of the appropriate emission units.

While New Zealand was committing itself to being part of the international effort to address anthropogenic climate change, intensive work was going on within government to create an appropriate domestic policy response. advice on domestic price signals for climate change in our economy from an eclectic range of stakeholders. The Labour government passed the Climate Change Response (Emissions Trading) Amendment Act 2008 into law just before it went out of office. The subsequent National-led government amended it, but kept the structure largely intact.

As noted earlier, climate change policy was an example of extreme polarisation of interests. But in the end Parliament at least agreed on a framework for a domestic carbon price, although there remain profound differences about how deeply that pricing signal should bite and who should pay. Interestingly, the environmental movement was somewhat divided on the relative merits of a carbon

\section{Internationally, we have clearly taken a significant reputational hit with our decision not to ratify Kyoto 2, the second phase of the Kyoto Protocol.}

This focused on creating what was described as a fiscally-neutral carbon tax, aimed at putting an effective price signal into the economy that would stimulate carbon reductions. Some complementary policies would sit alongside that. In terms of the wider context of this work, it proved to be perhaps the most divisive environmental debate of our time. We saw extraordinarily venomous tirades from the far right, from climate change deniers, from contrarians and from normally reasonable newspaper leader writers. We even saw a tractor being driven up the steps of Parliament by a National MP, with Federated Farmers as a cheerleader.

In the end, the carbon tax proposal failed when the government changed in 2005 and the support parties of the new, Labour-led government rejected it. The new government then looked at an emissions trading scheme. The Labour minister for climate change issues, David Parker, set up a Climate Leaders Forum (which in many respects operated analogously to the later Land and Water Forum). This sought to give the minister tax versus an emissions trading scheme. That remains the case to the present.

\section{Climate change: now}

We have now moved out of the intensive conflict phase into one where the issue has become something of a 'sleeper'. Federated Farmers has become more progressive and less climate-denying, which has contributed to the tonal shift in the domestic debate. And, of course, the science keeps moving on and the sceptics keep moving out. But at the same time - and I think this is partly because of a lack of effective communication from the scientific community in New Zealand, at least until recently - the climate change issue has virtually slipped from public view, notwithstanding that the northern hemisphere has tipped over the critical 40oppm $\mathrm{CO}_{2}$ mark, and that $\mathrm{New}$ Zealand is expected to do so in the next few years (Ministry for the Environment et al., 2009).

One reason for the policy slumber is that the government is not particularly interested in adding what it sees as a burden to an already struggling economy.
Indeed, it is heading in exactly the opposite direction, promoting the expansion of oil, gas and coal production as a core part of its economic strategy. Rather than reducing our use of fossil fuels, we are increasing it. In addition, the climate change minister has been preoccupied with other matters. Trade interests and New Zealand's United Nations ambitions trump climate change in our international positioning, and it is hard to see a minister who appears to be out of the country more than he is in it, and with such a big workload, taking a keen and active interest in pushing domestic policy along in a progressive way.

Internationally, we have clearly taken a significant reputational hit with our decision not to ratify Kyoto 2, the second phase of the Kyoto Protocol. Instead we have adopted a Clayton's position, where we are going to set a target and abide by the Kyoto 2 rules but not join it. The minister states that this is because there is a need to bring developing countries into a new framework, a point with which those countries that have signed up to Kyoto 2 would agree. We seem to have taken a perverse stance which is destroying a lot of the goodwill New Zealand built up in the international negotiations over many years.

Domestically, the carbon price is still extremely weak and the emissions trading scheme is not working as envisaged. Key emitters continue to be shielded, and there are large investments in dairy conversions supported by government subsidies and investment support for irrigation. The Ministry for Primary Industries wants to double the value of primary sector exports by 2025. Foresters are giving up and potential carbon sinks are being converted to emissions-intensive dairying. So there is no effective price signal that is going to change behaviour, and any moral authority that New Zealand may have had internationally is gone.

Why did this happen? Part of the reason is that climate change is a long-lived, extraordinarily difficult and complex policy issue, and it takes a lot of resources to maintain effective engagement. While some in the environmental movement are actively involved in climate change work, for others it takes a back seat to what are 
seen as more pressing and immediate matters. It is time, in fact, to hit the refresh key on this issue, and, to this end, in October leading environmental NGOs will be getting together to see how we can re-energise the climate change debate.

\section{Oceans policy: then}

I next want to look at oceans policy and the current interest in offshore oil, gas and mining.

Modern ocean policy had its inception in 1999, when officials were directed to investigate current arrangements for the management of New Zealand's marine environment. Shortly thereafter, the parliamentary commissioner for the environment released a report entitled Setting Course for a Sustainable Future: the management of New Zealand's marine environment, which identified a number of problems with the current system for managing New Zealand's oceans, and recommended the establishment of a Coastal and Oceans Task Force to develop a strategy for future sustainable management (Parliamentary Commissioner for the Environment, 1999). In July 2000 Cabinet endorsed a proposal to prepare an oceans policy for New Zealand, and in March 2001 a ministerial advisory committee was appointed to manage and lead the process of 'identifying the shared vision, goals and objectives of New Zealanders for managing New Zealand's oceans'.

Between June and August 2001 the committee undertook an extensive consultation process. A stocktake of legislation having an impact on oceans was completed in December 2002 and identified a number of weaknesses in the overall oceans management system. These included the absence of an overriding goal; inconsistent decisionmaking structures; opportunities for participation and management of like activities; ecologically arbitrary spatial management units; and a general lack of integrated management (Willis, Gunn and Hill, 2002).

The process came to a halt in July 2003 as a result of the controversy over Mãori ownership of the foreshore and seabed. However, a work stream continued to focus on achieving better management of the environmental effects of activities within the exclusive economic zone (EEZ). In June 2005 the Ministry for the Environment released a report, Offshore Options, which canvassed alternatives (Ministry for the Envirnoment, 2005). It recommended that a voluntary approach be adopted in the short term, but that overlay regulation, modelled on Australia's Environmental Protection and Biodiversity Conservation Act 1999, be prepared in the longer term.

In August 2007 the ministry released a more substantial discussion paper on the issue which took a different approach (Ministry for the Envirnoment, 2007). This ultimately resulted in Cabinet approval of proposals for an Exclusive Economic Zone (Environmental Effects) Act (EEZ there is a lot of interest in resources out there, how real that interest proves to be remains to be seen. Some mining proposals are advancing through the consenting process: for example, an application by Chatham Rise Phosphate is expected to be notified shortly. And, of course, there is a considerable interest in oil and gas exploration.

EDS saw some years ago that there was growing pressure on our oceans resource and that someone needed to be doing some serious thinking about it. It has therefore been the focus of a substantial portion of our policy work. Initially we looked at the need for an environmental protection authority. We saw that an EPA could evolve into an oceans regulator, and produced a paper that looked at such

\section{The BP Deepwater Horizon disaster in the Gulf of Mexico in April 2010 brought to the fore the dangers of New Zealand's lax environmental regulation within its exclusive economic zone.}

Act). Drafting of the bill commenced in 2008; however, this work was also put on hold when the government changed after the November 2008 general election.

The BP Deepwater Horizon disaster in the Gulf of Mexico in April 2010 brought to the fore the dangers of $\mathrm{New}$ Zealand's lax environmental regulation within its exclusive economic zone. When announcing the expansion of the newlyestablished Environmental Protection Authority (EPA) in May 2010, the minister for the environment indicated that the EPA could potentially undertake a consenting role under proposed EEZ legislation.

\section{Oceans policy: now}

The ocean is the last frontier. It has been, until quite recently, the wild west in terms of environmental regulation: there has been no effective environmental control over activities in our seas. New Zealand's ocean territory is the fourth largest in the world, which is extraordinary for a country of our size and population. While authorities around the world. It was, I think, influential in the overall outcome, particularly in the establishment of the EPA as an independent Crown entity.

The EPA is now the oceans regulator under the EEZ Act. The Act saw some spirited domestic debate about what it should contain and what its purpose and principles should be. Getting the early, unacceptable draft fixed took considerable effort from the environmental NGO community. Ultimately the act was passed in a reasonably acceptable form. There remains, however, an issue regarding the way the EPA boards of inquiry are appointed: it is a political process and is therefore open to stacking of panels with people with an axe to grind or with political affiliations, rather than people selected purely on the basis of their expertise and objectivity. This is in stark contrast to the Environment Court, with its independent status and expertise.

The Act and associated regulations came into force on 28 June 2013. The regulations identify which activities have 
'permitted activity' status under the act and the conditions for undertaking those activities without a marine consent. Generally, the regulations set out requirements for pre-activity notification, consultation with Māori and post-activity reporting to the EPA. The regulations also require operators wishing to carry out certain activities to undertake environmental assessments, and to have in place contingency plans in case something goes wrong.

The minister has been extensively lobbied by the petroleum sector, which is seeking to gain short-term advantage from having a government supportive of resource exploitation, over achieving longer-term stability and policy certainty. A second round of consultation is to the decision-making process, is of real concern. It is an issue that will burgeon into a much bigger and more public one in the second half of this year.

\section{Marine reserves: then}

New Zealand was one of the first countries to consider the development of legislation that would provide for the spatial protection of the marine environment. In 1965 Professor Chapman, chairman of the University of Auckland's Leigh Marine Laboratory Committee, wrote to the government Marine Department to suggest that a no-take marine reserve in front of the laboratory be established. He argued that this would enable the area to be restored to its natural state, thus improving the effectiveness of scientific

\section{The [Marine Reserves Act] was brought about by intensive lobbying from the scientific community, rather than as a result of government having a specific desire to implement measures for marine protection ...}

commence shortly, with the minister, Amy Adams, having indicated that she is going to amend the EEZ Act to create a new category called 'non-notified discretionary' for oil and gas exploration drilling. That effectively means that the EPA will process consents for exploration wells in-house with no formal public comment. When one considers that the Deepwater Horizons well in the Gulf of Mexico was an exploration well, and the extent of damage that can occur if something goes wrong, it seems an extraordinary proposition to exclude the public, minimise transparency, and give an industry group operating in our deep oceans a pass-through process in which there is no rigour, no ability to crossexamine applicants as to their reputation and experience, and no opportunity for the calling of expert evidence to discuss the environmental effects of what is proposed on marine mammals or other valued oceans ecosystems. All of that, coupled with politicisation of study there (Ballantine, 1991). Six years later, in 1971, the Marine Department released a draft bill, and the Marine Reserves Act was subsequently passed. The University of Auckland then made an application for the establishment of a marine reserve in front of the Leigh Laboratory. This first application was rejected, another submitted in 1973, and finally accepted in 1975, making the Cape Rodney-Okakari Point marine reserve the first to be established in New Zealand. It was also one of the first no-take marine reserves to be established under speciallydesigned legislation anywhere in the world. The act was brought about by intensive lobbying from the scientific community, rather than as a result of government having a specific desire to implement measures for marine protection (Mulcahy and Peart, 2010).

More recently the Marine Reserves Bill was introduced into Parliament on 7 June 2002, passed its first reading in October that year and was referred to the Local
Government and Environment Select Committee. The bill aimed to resolve what were seen as the key problems with the Marine Reserves Act 1971, and which rendered it inconsistent with current government policy, in particular the government's biodiversity strategy. The act also only applied to the territorial sea. Progress of the bill through Parliament then stalled for a decade, however, and the creation of new marine reserves slowed to a trickle.

\section{Marine reserves: now}

Earlier this year the minister of conservation created a new marine reserve in Akaroa Harbour after more than a decade in process. There the obstacle was a difference of opinion between local iwi and fishers, and the Akaroa Harbour Marine Protection Society. Initially the minister declined the application. EDS provided legal assistance to the society, and the decision was overturned in the High Court. This was an instance where litigation played a critical role in policymaking. It demonstrates the importance of having appeal and judicial review entitlements to keep errant ministers in check. It was also a poor process, as this application and many others before it were mired in conflict and controversy. It was the last application of its kind in the pipeline.

The difficulties with implementing marine reserves led the government to announce that it would reform the Marine Reserves Act by broadening its purpose and modernising its community consultation processes. More recently the minister has indicated to us that he will be putting that review of the Marine Reserves Act on hold. Instead, Minister Nick Smith intends to have a wider look at protected marine areas across our oceans resource extending beyond the 12nautical-mile limits.

I believe that is the right way forward. Tinkering with a 1971 piece of legislation will be inadequate to meet the needs of the 21st century. The 2002 bill is too limited as well as dated, and was discharged from Parliament earlier this year. We now need a process that looks at some of the exciting conservation opportunities on offer in our exclusive economic zone and 
extended continental shelf. This exercise should be part of a wider national conversation about oceans reform. The successful approach on freshwater policy offers a useful indication of how getting competing interests into a room can work. I believe that such a conversation needs to look across the entire marine field, including aquaculture, fishing, recreation, minerals, shipping, conservation and pollution. EDS is scoping out such an exercise with both government and within civil society.

The Auckland and Waikato councils have approved a marine spatial planning exercise for the Hauraki Gulf, the most intensively used part of our marine environment. This will follow a collaborative approach and will be a useful pilot for a wider national exercise.

\section{Freshwater: then}

In 1980 leaders of the environmental movement of the time felt that there was a need to be able to take a conservation initiative to protect rivers, instead of being limited to reacting to development proposals, especially for hydro generation, irrigation and aluminium smelters. The idea was to amend the Water and Soil Conservation Act 1967 to enable water conservation orders to be created to protect 'wild and scenic rivers'. The proposal had strong backing from the minister for the environment, Ian Shearer, and some other National MPs, including Paul East, Doug Kidd and Ian McLean. Ultimately it also had support from Energy Minister Bill Birch and Prime Minister Rob Muldoon.

I remember Bryce Johnson, from the acclimatisation societies, Guy Salmon and others actively lobbying around the Beehive for the creation of this new initiative. Some of us used the minister for the environment's office as an informal campaign headquarters for weeks on end and lobbied across the House to get the support that was required to bring that bill to fruition. (How things have changed!)

The Water and Soil Amendment Act 1981 was passed and the first water conservation order, for the Motu River, was approved early in that decade. Those amendments were carried over into the Resource Management Act in 1991, and remain there. Today there are 15 water conservation orders, most of them as a result of acclimatisation societies and Fish and Game initiatives.

The wild and scenic rivers law was enacted after some old-fashioned lobbying, gaining support of key parliamentarians, and a supportive public campaign which garnered widespread popular endorsement. It is a conservation initiative that has stood the test of time.

\section{Freshwater: now}

The broader issue of freshwater management has been a challenge for policymakers for some years. A Sustainable Water Programme of Action led by the Ministry for the Environment between 2003 and 2008 failed. Then, in 2008 at green side thinking that we had been shafted. But we got over ourselves.

The 156 Land and Water Forum recommendations have now been passed on to the government with a strict caveat, supported by all, that it should not 'cherry pick'. What is required is that the government adopts the Land and Water Forum recommendations as a package. In its announcement of the first stages of reform it appeared that some cherrypicking was, in fact, in prospect. In more recent times wiser heads are prevailing and the government has come back more directly to the forum's recommendations. Crucially, the government's discussion paper postulated a weakening of water conservation orders. There has since been some retreat from that position,

\section{The Land and Water Forum brought all stakeholders who had an interest in freshwater, including, crucially, iwi leaders, into the room.}

EDS's annual conference, a group of diverse interests together decided that we had had enough of litigating our differences in the Environment Court. Parties as diverse as Fish and Game, Forest and Bird, EDS, Federated Farmers and Fonterra signed a communiqué which led to the creation of what was initially called the Sustainable Land Use Forum. This initiative secured the National-led government's support and the Land and Water Forum was established.

The Land and Water Forum brought all stakeholders who had an interest in freshwater, including, crucially, iwi leaders, into the room. After three years of an interesting, challenging and dynamic process, it had arrived at an agreed set of recommendations for freshwater reform, contained in three successive reports. Challenges during the process included the government creating a national policy statement on freshwater management which was a considerably weakened version of that recommended by its board of inquiry. That threatened to destroy the forum, with many on the with 'ambiguity' in the document being cited. Cabinet minutes show, however, that in the longer term the prospect of weakening water conservation orders remains. Given the history I have outlined and the fact that those orders are the only way we can take conservation initiatives for freshwater, any weakening will lead to very robust debate.

The Land and Water Forum was a collaborative process. Collaboration means getting everybody to change their minds. It necessarily involves the creation of a consensus, which means everybody's position or opening gambit has to shift and that occurs through a process of dialogue, through understanding the background science more thoroughly, through understanding the competing pressures on the resource, and the need to be practical but at the same time have a trajectory that is going the right way. But having arrived in a relatively good place itself, the forum is now dependent on government for implementation, and that will take some years. The first tranche of decisions has been announced and is acceptable. There is still the risk, 
though, that government will depart from the forum consensus, invoke a weak national objectives framework or make fundamental changes to the underlying legislation.

\section{Resource management law: then}

The second major environmental reform that occurred during the late 1980 s was the creation of the Resource Management Act 1991 (RMA). This collapsed 78 existing statutes and regulations into a single omnibus piece of legislation governing the use of all air, land and water in New Zealand. It was then and is now worldleading law.

It is worth first reflecting on a precursor to the act, the National Development Act 1979. That act allowed (iii) The major expansion of exports or of import substitution; or

(iv) The development of significant opportunities for employment; and

(b) That it is essential a decision be made promptly as to whether or not the consents sought should be granted. (Section 3(3))

The Act required an environmental impact report to be prepared and audited. Strict time constraints were placed on the process. After the report was received, public notice was given of the inquiry and a wide range of parties were able to be heard. Under section 9 the Planning Tribunal had to consider the same matters and give these the same weight as a consent authority if the

\section{The Resource Management Act ... got bipartisan support in out pre-MMP Parliament. It has retained that support until recently.}

for the bypassing of planning procedures under the Town and Country Planning Act 1977. The long title of the National Development Act read:

An Act to provide for the prompt consideration of proposed works of national importance by the direct referral of the proposals to the Planning Tribunal for an inquiry and report and by providing for such works to receive the necessary consents.

The Act applied to works which were considered by the Governor-General in Council to be 'a major work that was likely to be in the national interest', and where it was considered:

(a) That the work is essential for the purposes of -

(i) The orderly production, development, or utilisation of New Zealand's resources; or

(ii) The development of New Zealand's self sufficiency in energy (other than atomic energy as defined in section 2 of the Atomic Energy Act 1945); or applicant had applied for consents in the normal way. After the Planning Tribunal conducted the public inquiry and released its recommendations, the GovernorGeneral in Council could declare work to be of national importance and grant consents (with or without conditions). The governor-general in council only had to take into account the report and recommendation of the Planning Tribunal. There were restrictions on appeal rights - they had to be taken in the Court of Appeal and there was no appeal available from that decision.

The National Development Act, which was repealed by the Labour government in 1986, sought to fast-track major energy-related projects. It has obvious parallels today.

The Resource Management Act was initially the brainchild of the 1987 Labour government's minister for the environment, Geoffrey Palmer. $\mathrm{He}$ produced a 314-page bill which was introduced into Parliament in 1988. When the government changed in 1990, the new minister for the environment in the National government, Simon Upton, took over the process. He set up an advisory group whose members included Tony Randerson, now a judge in the Court of Appeal, and Guy Salmon: the group was, if you like, the equivalent of what we would call a technical advisory group today. The review panel recommended some changes, which were largely adopted by the government. In his third reading speech to the House, Simon Upton made the following observations:

The Bill provides us with a framework to establish objectives with a biophysical bottom line that must not be compromised. Provided that those objectives are met, what people get up to is their affair. As such, the Bill provides a more liberal regime for developers. On the other hand, activities will have to be compatible with hard environmental standards and society will set those standards. Clause 4 sets out the biophysical bottom line. Clauses 5 and 6 set out further specific matters that expand on the issues. The Bill has a clear and rigorous procedure for the setting of environmental standards - and the debate will be concentrating on just where we set those standards. (Upton, 1991)

The act was passed with bipartisan support from both National and Labour and came into force in 1991.

The Resource Management Act came about through a fairly conventional process. Environmental groups had been active in lobbying for its creation, and it was an idea that had merit and whose time had come. It reflected modern international thinking about sustainability and embodied the environmental values emerging then in the wider community. It also embraced a move away from centralised, override planning, most noticeably evident in the National Development Act. It reached across the political spectrum and got bipartisan support in our pre-MMP Parliament. It has retained that support until very recently.

\section{Resource management law: now}

The poor old RMA has gone through reform after reform, and I must say, as a user of it, that it is difficult to navigate 
and is hardly a model of statutory drafting. But it does not deserve all the bad press it gets, which is often based on exaggeration, self-serving commentary and misrepresentation.

There are four current reforms that I want to address.

\section{Resource Management Reform Bill}

The government introduced the Resource Management Reform Bill in 2012. This bill, among a number of other changes, creates a fast-track process for the Auckland Unitary Plan, makes changes to section 32 of the RMA, and seeks to further restrict the ability of councils to protect trees in urban areas by overriding a 2011 Environment Court decision. At the time of writing the select committee has reported on the bill and it is awaiting its committee stages in the Parliament. Few changes were made and there was no agreement between parties on the controversial elements. The restrictions on tree protection are particularly controversial. The amendments mean that protected trees must be identified in a schedule listing the land they are located on and describing the tree or group of trees. The amendments appear to be intended to make tree protection more difficult so as to discourage councils from tree protection. It is creating bureaucratic obstacles rather than simplifying processes.

Technical advisory group on sections 6 and 7 The next round of RMA reforms began with the minister for the environment appointing a technical advisory group in October 2011 to review sections 6 and 7 of the RMA. The group's terms of reference were to:

provide independent advice to the Minister for the Environment on any changes needed to sections 6 and 7 of the RMA to improve the functioning of the RMA relative to: 20 years' practical experience of its operation; the Government's environmental and economic objectives; and the broader second phase of resource management reforms. (Minister for the Environment's Resource Management Act 1991 Principles Technical Advisory Group, 2012)
The technical advisory group report was released July 2012 and made a number of controversial recommendations. The key recommendations were:

1. combining sections 6 and 7 and removing the existing hierarchy between the two sets of principles;

2. removing directive terms such as 'protect' and 'maintain';

3. removing a number of existing principles, including 'maintaining and enhancing amenity values';

4. adding a number of principles relating to the benefits to be derived from the use and development of resources, infrastructure, and the built environment and urban expansion;

5. adding a new section addressing social outcomes (Environmental Defence Society Technical Advisory Group, 2012).

The government released its proposals for the stage two RMA reforms in its discussion document Improving Our Resource Management System in February this year (Ministry for the Environment, 2013). It received about 14,000 submissions. There are a number of proposals in the discussion document which are likely to improve our resource management system, including a national template for resource management plans, standard definitions, and more mandatory timelines for processing resource consents. However, some of the proposals are deeply troubling and if implemented are likely to lower environmental standards across New Zealand. Of most concern are:

\section{There are a number of proposals in the discussion document which are likely to improve our resource management system, including ... more mandatory timelines for processing resource consents.}

\begin{abstract}
matters of 'process', including a requirement for decision-makers to 'achieve an appropriate balance between public and private interests in the use of land'. (Ibid.)
\end{abstract}

Prior to the release of the government's technical advisory group report, EDS convened its own advisory group, which included a more experienced multi-disciplinary team of resource management professionals, including a former High Court Judge, with the same terms of reference as the minister's. The EDS technical advisory group came to substantially different conclusions. It considered that providing for economic or social outcomes in section 6 was undesirable because it would increase the likelihood of conflict between section 6 matters, introduce uncertainty and lead to more litigation. It would also run counter to the approach of focusing on the effects of activities on the environment, rather than attempting to direct or provide for certain economic or
- The proposed changes to the principles of the RMA (contained in sections 6 and 7 ), including:

(a) removing the hierarchy between section 6 (matters of national importance) and section 7 (other matters);

(b) deleting core environmental principles, including the 'maintenance and enhancement of amenity values', 'intrinsic values of ecosystems' and 'the ethic of stewardship';

(c) adding new development principles, including 'the efficient provision of infrastructure'.

- Proposals to increase the powers of ministers while reducing the rights of communities and the role of the Environment Court, including:

(a) granting ministers greater powers to intervene in plan-making processes, including powers to specify the outcome of a planmaking process and directly amend an operative plan through regulations; 
(b) introducing limitations on the scope of submissions and appeal rights;

(c) reducing the role of the Environment Court by:

- changing appeals from de novo (considered afresh) to a rehearing (considered on the basis of evidence presented at the council hearing);

- removing merit appeal rights where a single resource management plan is produced.

Consultation on the RMA discussion document has now closed. A summary report is anticipated imminently and we expect a bill to be released in the coming months.
- When a resource consent is considered in a special housing area, the bill does not require application of the RMA or plans. Instead, the decision-maker only has to have regard to these matters, and can disregard them in the name of affordable housing. Public participation is highly restricted.

This can only lead to poor social and environmental outcomes - or slums. In addition, the bill allows the government to create special housing areas and undertake resource consenting on its own where it cannot reach a housing accord with a council. The bill also limits appeal rights considerably.

\section{The RMA reforms ... are examples that demonstrate that the government is becoming more radical and is willing to ride rough-shod over due process.}

\section{The Housing Accords and Special Housing} Areas Bill

Along with the troubling RMA reforms, we also have a proposed RMA override bill. The Housing Accords and Special Housing Areas Bill was introduced largely in response to the perceived housing crisis in Auckland. The purpose of this bill is 'to enhance housing affordability by facilitating an increase in land and housing supply in certain regions or districts ... identified as having housing supply and affordability issues'. It provides for the government to enter into a housing accord with councils and then to establish special housing areas in which planning provisions will be weakened to enable resource consents to be obtained.

We have real concerns with this:

- Once a special housing area is identified, there will be an expectation that development will be allowed; however, the bill does not put in place any requirements to consider environmental effects (or social or economic effects) during the identification of special housing areas.

\section{The New Zealand Public Health and Disability Amendment Act 2013}

I want now to step outside environmental law for a moment to highlight where the trend might be going with respect to public access to the law. The New Zealand Public Health and Disability Amendment Act 2013 amends the New Zealand Public Health and Disability Act 2000, which provides for the public funding and provision of health services and disability support services. The amendment is a response to a Court of Appeal decision that the policy of not paying family carers to provide support services to disabled family members constituted unjustifiable discrimination on the basis of family status. This legislation was rushed through Parliament: it was passed the day it was introduced. There was no select committee process for the public to participate in, which completely ignored proper process in a situation where there was no need for such extreme haste.

Significantly, the legislation contains provisions which limit the rights of people to seek redress when they believe that certain rights set out in the Human Rights Act 1993 and the Bill of Rights Act
1990 (freedom from discrimination on the basis of marital status, disability, age or family status) have been breached by the act or decisions made under it.

In respect of such allegations, 'no complaint based in whole or in part on a specified allegation may be made to the Human Rights Commission, and no proceedings based in whole or in part on a specified allegation may be commenced or continued in any court or tribunal' (section $70(\mathrm{E})(2)$ as amended). This is an ouster clause, which restricts the ability of persons to test the legality of decisions in the courts, including by judicial review. It is constitutionally obnoxious and the Legislation Advisory Committee has emphasised that such clauses should be used only in exceptional cases (Legislation Advisory Committee, 2001, chapter 13).

The overall trend with RMA and related reforms is one of weakening the core legislation, fast-tracking consenting and plan-making, limiting rights of public participation and legal standing, reducing the role of the Environment Court, replacing it with politically-appointed commissioners in many instances, limiting rights of appeal, and picking winners (mostly from the resources sectors). If this sounds like the national development era revisited by stealth, then it is. We are slowly seeing a usurpation of decision-making powers by ministers, a commensurate reduction in the role of the courts, a reversing of the doctrine of subsidiarity and an overall lowering of environmental standards.

The RMA reforms, including the Housing Accord Bill (and the Public Health and Disability Amendment Act) are examples that demonstrate that the government is becoming more radical and is willing to ride rough-shod over due process. All this has big environmental implications. It is absolutely true that in the resource management world we are seeing a revisiting of the 'Think Big' era, with the same emphasis on resource extraction and fast-tracking approval processes in constitutionally questionable, if not obnoxious, ways.

\section{Conclusions}

There is a wide range of ways in which environmental policy and law has been made 
over the past 30 years. They include bipartisan agreements between political parties (these days we would say multi-partisan agreements); old-fashioned lobbying with town hall meetings, pamphlets and pressuring individual MPs towards a point of view; working creatively with like-minded parliamentarians within the parliamentary precinct to build agreement with their colleagues on initiatives they are prepared to support; preparing, well in advance of the issue becoming contemporary, wellthought-out policy papers that influence the way that policy and law is made; strategic litigation; and using advisory groups to assist ministers with advice on how to proceed.

There is another way to make good policy: through collaboration. This concept is relatively new to New Zealand, having been imported from Scandinavia by Guy Salmon. It had its first run in the Land and Water Forum, but has morphed into wider use: the Mackenzie Country Shared Vision Forum; Auckland Council's Transport Funding Group; and the proposed Hauraki Gulf Marine Spatial Planning Forum. In collaborative processes, if all the stakeholders agree on a reform prescription they are much more likely to get cross-party support, which is what has largely happened with freshwater. Policy is also likely to be more enduring over time. This is the opposite of shortterm opportunistic policy gaming. The oil and gas sector is engaging in that. It is trying to get the easiest set of regulations it can to enable its activities over the next few years. The upshot will be a massive lurch in the opposite direction when the government changes, as they do.

We will also see a swift and determined change of direction on climate change when the government changes. Sleeping on something that important is not a durable position for a country to take. If ministers are going to insist on changes to part 2 of the RMA, which many experts, including Sir Geoffrey Palmer, say will lower environmental standards, then there will be a repeal of those provisions when the government changes. But constant change is destabilising and creates investment uncertainty. It is not good to have extreme policy lurches.

So what about a collaborative approach towards RMA reform? What about a collaborative approach around the oil and gas regulations, where we actually get to sit down with the sector and the government and its advisors and talk about what can work and what does not work for everybody, rather than proceeding on a deep suspicion that multinationals are calling the shots for short-term advantage? What about a collaborative process around the really big environmental policy issue which is still before us - namely, oceans management?

My contention is that some of these big environmental policy decisions are too big to play politics with; that it is time for civil society to undertake more of the kind of collaborative processes that we have seen emerging. We should take more of the initiative around our precious environment away from direct government control and initiate civil society-led reform. We should see government as a servant rather than a master and initiate more Land and Water Forum-type exercises. In the meantime, the government needs to moderate its extremist incursions on the environment.

\section{References}

Ballantine, B. (1991) Marine Reserves for New Zealand, Auckland: University of Auckland

Cullen, M. (1983) Speech by Dr Michael Cullen, 21 June

Department of Conservation (2013) 'DOC proposes changes to increase conservation', media release, 26 March

Environmental Defence Society Technical Advisory Group, Report on the Review of Sections 6 and 7 of the Resource management Act 1991, Auckland: Environmental Defence Society

Ericksen, N..J., P.R. Berke, J.L. Crawford and J.E. Dixon (2004) Planmaking for Sustainability: the New Zealand experience, Aldershot: Ashgate Publishing Limited

Legislation Advisory Committee (2001) Guidelines on Process and Content of Legislation, Wellington: Legislation Advisory Committee

Minister for the Environment's Resource Management Act 1991 Principles Technical Advisory Group (2012) Report of the Minister for the Environment's Technical Advisory Group, Wellington: Ministry for the Environment

Ministry for the Environment (2005) Offshore Options: managing environmental effects in New Zealand's exclusive economic zone, Wellington: New Zealand Government

Ministry for the Environment (2007) Improving Regulation of Environmental Effects in New Zealand's Exclusive Economic Zone: discussion paper, Wellington: New Zealand Government
Ministry for the Environment (2013) Improving Our Resource Management System: a discussion document, Wellington: New Zealand Government

Ministry for the Environment, New Zealand Aid and International Development Agency and National Institute of Water and Atmospheric Research (2009) New Zealand's Fifth National Communication under the United Nations Framework Convention on Climate Change, including the Report on the Global Climate Observing System, Wellington: New Zealand Government

Mulcahy, K. and R. Peart (2012) Safeguarding Our Oceans: strengthening marine protection in New Zealand, Auckland: Environmental Defence Society

Parliamentary Commissioner for the Environment (1999) Setting Course for a Sustainable Future: the management of New Zealand's marine environment, Wellington: Office of the Parliamentary Commissioner for the Environment

Royal Forest and Bird Protection Society of New Zealand, Federated Mountain Clubs, Native Forests Action Council, Environmental Defence Society, Greenpeace and ECO (1985) Environmental Administration in New Zealand: an alternative discussion paper, Nelson: Environment Administration Task Group

Upton, S. (1991) New Zealand Parliamentary Debates, 516, Resource Management Bill Third Reading, pp.3018-3020

Willis, G., J. Gunn and D. Hill (2002) Oceans Policy Stocktake Prepared for the Oceans Policy Secretariat, Auckland: Enfocus Limited 